\title{
Ballistic Tests of Alumina-UHMWPE Composites Submitted to Gamma Radiation
}

\author{
André Ben-Hur da Silva Figueiredo ${ }^{a}$ ¿ \\ Lima Júnior ${ }^{a}$, João Gabriel Passos Rodrigues ${ }^{a}$, Letícia dos Santos Aguilera $^{a}$, Ronaldo Sergio de Biasi ${ }^{a}$
}

${ }^{a}$ Seção de Engenharia de Materiais, Instituto Militar de Engenharia, Rio de Janeiro, RJ, Brasil
${ }^{b}$ Centro Tecnológico do Exército, Departamento de Irradiações, Rio de Janeiro, RJ, Brasil

Received: March 19, 2019; Revised: May 09, 2019; Accepted: June 10, 2019

\begin{abstract}
The energy absorption in ballistic tests of alumina-ultra high molecular weight polyethylene (UHMWPE) composites with 60, 80 and $90 \mathrm{wt} \%$ alumina submitted to gamma radiation doses of 25,50 and $75 \mathrm{kGy}$ was investigated. The ballistic tests were carried out at subsonic speed using a compressed air system. The results showed that the composite with $80 \%$ alumina irradiated with $50 \mathrm{kGy}$ yields the best ballistic results. Gel content, Differential scanning calorimetry (DSC) and X-ray diffraction (XRD) results showed that this composite is the one with the highest concentration of crosslinks and the lowest volume fraction of amorphous UHMWPE. Scanning electron microscopy (SEM) images of the same composite showed a high pullout, suggesting that gamma irradiation increases the adhesion between alumina and UHMWPE.
\end{abstract}

Keywords: Ballistic shielding, ballistic impact, alumina-UHMWPE composite, gamma irradiation.

\section{Introduction}

In the beginning of the 21 st century, despite the absence of international conflicts on the scale of the two World Wars, local and regional conflicts involving different tribes, ethnic groups, militias, gangs and heavily armed drug dealers have become a serious threat in several parts of the world.

Standard bulletproof personal protection vests use aramid fabric as a single layer of shielding. This protection is limited to relatively low impacts, up to $9 \mathrm{~mm}$ ammunition. Protection against high impact projectiles requires a multiagent system (MAS) ${ }^{1}$. A conventional MAS has, beside the aramid fabric, a ceramic front layer which absorbs most of the impact energy, eroding the projectile tip. However, such protection increases the cost and compromises the soldier mobility due a significant increase of vest weight. In addition, the front layer may be fragmented by the first impact, compromising its resistance to subsequent shots.

The main ceramic materials used for ballistic protection are alumina $\left(\mathrm{Al}_{2} \mathrm{O}_{3}\right)$, silicon carbide $(\mathrm{SiC})$ and boron carbide $\left(\mathrm{B}_{4} \mathrm{C}\right)$. Alumina has been suggested for ballistic protection due to good physical and chemical properties. However, the low flexural strength and low fracture toughness mean that the use of pure alumina for ballistic protection may lead to catastrophic failure. Moreover, the high density, about $4 \mathrm{~g} / \mathrm{cm}^{3}$, limits its use in applications where weight is crucial, such as bulletproof vests ${ }^{2,3}$.

According to Figueiredo et al. ${ }^{4}$, alumina-UHMWPE composites may yield a good compromise between high energy absorption and low density, the only problem being low adhesion between the alumina particles and the polymer matrix ${ }^{5}$. The adhesion may be increased by exposure of the composites to gamma radiation ${ }^{6,7}$, that has other favorable effects, such as increased stiffness and stability, as reported by Shafiq. et al. ${ }^{8}$.
On the other hand, according to Hobbs et al. ${ }^{9}$, high radiation doses generate microcracks that weaken the alumina component.

The purpose of this work was to investigate the properties of gamma irradiated alumina-UHMWPE in order to determine the best combination of alumina concentration and radiation dose for ballistic protection applications. The UHMWPE is used to decrease the density and increase the flexural strength, making the shield more suitable for personal protection and avoiding fracture after the first shot ${ }^{10,11}$. There is also an economic factor involved, since the composite is prepared at a relatively low temperature, $230^{\circ} \mathrm{C}$, while pure alumina must be prepared sintering alumina powder at high temperatures, of the order of $1400{ }^{\circ} \mathrm{C}$, a more expensive procedure ${ }^{12-15}$.

\section{Materials and methods}

\subsection{Materials}

The materials used were 60 Mesh Alundum powder with 9.25 Mohs hardness (Fisher Scientific) and UHMWPE Mipelon PM-200 powder $10 \mu \mathrm{m}$ to $30 \mu \mathrm{m}$ in diameter (Mitsui Chemicals).

\subsection{Sample preparation}

Composites with different alumina-UHMWPE mass ratios were prepared by mechanical mixing for $10 \mathrm{~min}$ and labeled A00/00, A00/25, A00/50, A00/75, A60/00, A60/25, A60/50, A60/75, A80/00, A80/25, A80/50, A80/75, A90/00, A90/25, A90/50 and A90/75, where the first number is the alumina (A) mass concentration in percent $(00$ is a pure UHMWPE sample used for comparison). The second number is the radiation dose in $\mathrm{kGy}$ (00 is non-irradiated sample).

*E-mail: abenhur@ime.eb.br 
The samples were produced in the shape of discs $5 \mathrm{~mm}$ thick and $51 \mathrm{~mm}$ in diameter. The discs were pressed at $230{ }^{\circ} \mathrm{C}$ for $10 \mathrm{~min}$ under a force of $90 \mathrm{kN}$ and kept in cast aluminum forms.

Gamma Irradiation of the composites was performed using a Gammacell 220 Excel irradiator with a Co-60 source.

\subsection{Ballistic tests}

For the ballistic tests, an air rifle Gunpower SSS was used with a noise suppressor Padrão Armas. The projectile was a 22 gauge lead shot with an estimated mass of $3.3 \mathrm{~g}$. An Air Chrony ballistic chronograph model MK3, with a precision of $0.15 \mathrm{~m} / \mathrm{s}$, was used to measure the impact speed, and a ProChrono ballistic chronograph model Pal, with a precision of $0.31 \mathrm{~m} / \mathrm{s}$, was used to measure the residual speed.

The air rifle was positioned $5 \mathrm{~m}$ away from the target, consisting of the composite disk attached in an aluminum frame, secured by a bench vise and aligned perpendicularly to the rifle. One ballistic chronograph was positioned $10 \mathrm{~cm}$ from the nozzle of the noise suppressor and another was placed $10 \mathrm{~cm}$ behind the target.

The energy absorbed by the target was calculated using the equation

$$
E_{a b s}=m_{p}\left(v_{i}^{2}-v_{r}^{2}\right) / 2
$$

where $m_{p}$ is the projectile mass, $v_{i}$ is the impact speed and $v_{r}$ is the residual speed ${ }^{16}$.

Taking into account the fact that in the case of personal protection weight may be an important factor, one may define a figure of merit given by the following equation:

$$
F M=E_{a b s} / m_{c}
$$

where $m_{c}$ is the composite mass.

\subsection{Gel content measurements}

The gel content shows the amount of crosslinking in the samples. It was determined according to ASTM D2765 using a Soxhlet device ${ }^{15}$. The samples were extracted using boiling xylene for $6 \mathrm{~h}$ and were subsequently washed with acetone and dried at $140{ }^{\circ} \mathrm{C}$. The percent gel content was determined using the following expression:

$$
\text { gel content }=\left(W_{1} / W_{o}\right) 100 \%
$$

where $W_{\mathrm{o}}$ and $W_{1}$ are, respectively, the weight of sample before and after extraction.

\subsection{Differential scanning calorimetry}

Differential scanning calorimetry (DSC) analysis was performed with a Netzch DSC 404 F1 Pegasus calorimeter. The measurements were carried out with a heating and cooling rate of $10{ }^{\circ} \mathrm{C} \mathrm{min}{ }^{-1}$ under nitrogen $\left(50 \mathrm{~mL} \mathrm{~min}^{-1}\right)$.
The samples were heated from room temperature to $180^{\circ} \mathrm{C}$ and cooled to $50{ }^{\circ} \mathrm{C}$ and then reheated to $180^{\circ} \mathrm{C}$. The melting temperature and the percent crystallinity was determined only for the first run. The percent crystallinity $X c$ was calculated using the following expression:

$$
X_{c}=\left(\Delta H_{o} / \Delta H_{m}\right) 100 \%
$$

where $\Delta H_{\mathrm{o}}$ and $\Delta H_{\mathrm{m}}$ are, respectively, the enthalpy of melting of crystalline polyethylene $\left(290 \mathrm{Jg}^{-1}\right)$ and the enthalpy of melting of the sample.

\subsection{X-ray diffraction}

The sintered samples were characterized by X-ray Diffraction (XRD) in an X'PERT PRO PANalytical diffractometer, with monochromatic radiation $\left(\mathrm{Cu} \mathrm{K} \alpha, \lambda=1.5406^{\circ} \mathrm{A}\right)$, step size of $0.05^{\circ} \mathrm{s}^{-1}$, time per step $150 \mathrm{~s}$ and $2 \theta$ between $10^{\circ}$ and $90^{\circ}$. The XRD patterns were refined using the Rietveld method, with the help of the TOPAS Academic version 4.1 software.

\subsection{SEM images}

After the ballistic tests, images of composites with $80 \%$ alumina were taken in a FEI Quanta FEG 250 SEM.

\section{Results and discussion}

\subsection{Ballistic tests}

All shots completely penetrated the disks. Two shots were made in each experiment and eight experiments were performed for each composition. Representative samples are shown in Figure 1 after the first shot.

No significant decrease in energy absorption was observed after the first shot.

Since the test was performed with the samples in the cast aluminum holders, lateral movement was suppressed, reducing the damage to the composite ${ }^{17,18}$.

Table 1 shows the average values of the composite mass $\left(m_{c}\right)$. projectile mass $\left(m_{p}\right)$, average impact speed $\left(v_{i}\right)$, average residual speed $\left(v_{r}\right)$, absorption energy $\left(E_{a b s}\right)$ and merit factor $(F M)$ for each composition. As expected, $m_{c}$ increases with increasing alumina concentration.

Figure 2 shows the FM of composites with different alumina concentrations and radiation doses. One can see that the best compromise between high energy absorption and low weight was displayed by the composite with $80 \%$ alumina irradiated with $50 \mathrm{kGy}$.

\subsection{Gel content measurements}

Table 2 shows that the gel content of UHMWPE, nonirradiated and gamma irradiated with doses of $25 \mathrm{kGy}$, $50 \mathrm{kGy}$ and $75 \mathrm{kGy}$. The highest gel content was for the samples irradiated with a dose of $50 \mathrm{kGy}$, suggesting the concentration of crosslinks is maximum for this radiation dose. 

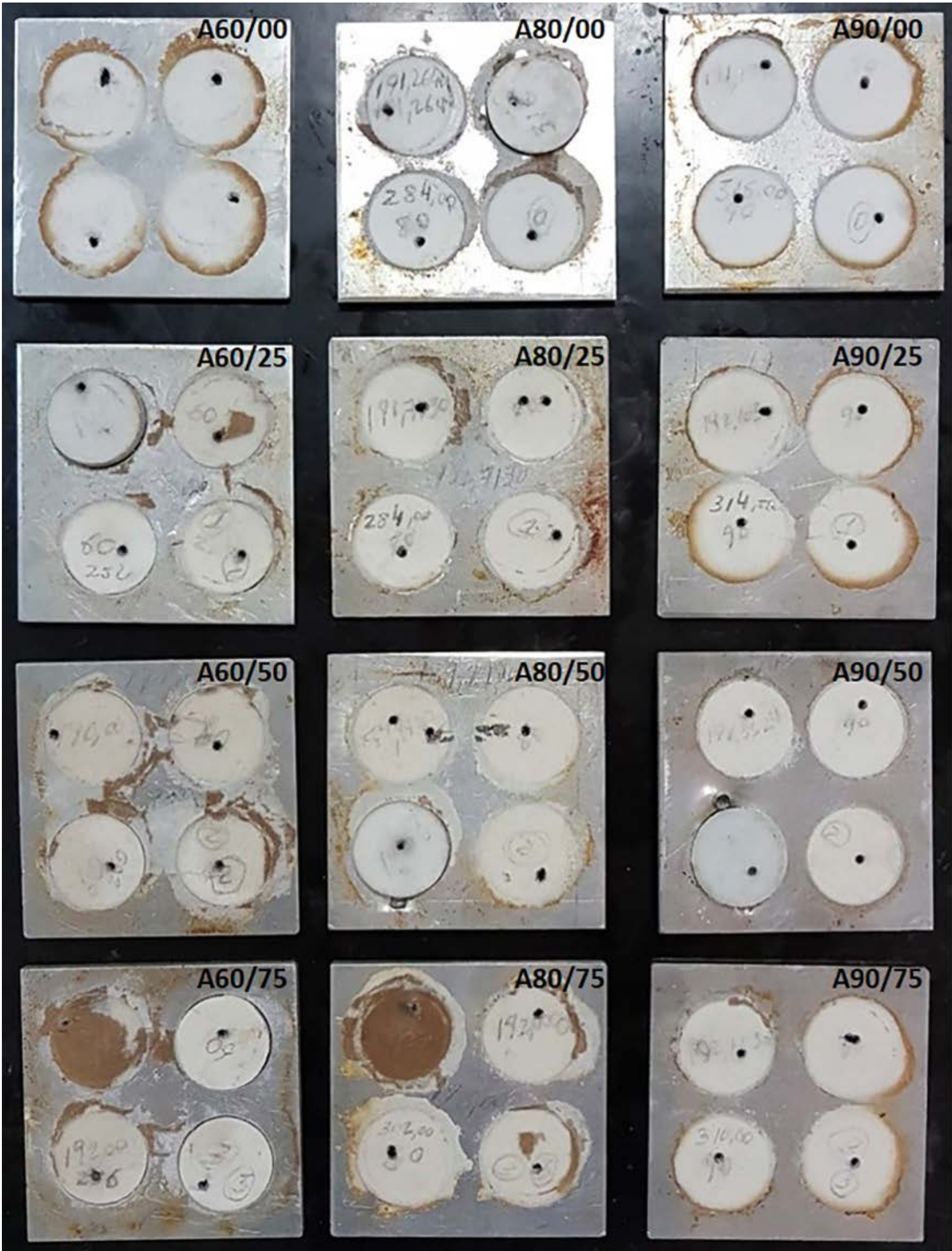

Figure 1. A60/00, A60/25, A60/50, A60/75, A80/00, A80/25, A80/50, A80/75, A90/00, A90/25, A90/50 and A90/75 samples after the first shot, arranged in top-down rows. 
Table 1. Average results of the ballistic tests.

\begin{tabular}{|c|c|c|c|c|c|c|}
\hline COMPOSITE & $\mathrm{m}_{c}(\mathrm{~g})$ & $\mathrm{m}_{p}(\mathrm{~g})$ & $\left.\mathbf{V}_{i} \mathbf{m} / \mathbf{s}\right)$ & $\mathrm{V}_{r}(\mathrm{~m} / \mathrm{s})$ & $\mathbf{E}_{a b s}(\mathbf{J})$ & FM $\left(10^{3} \mathrm{~J} / \mathrm{kg}\right)$ \\
\hline A60/00 & $16.50 \pm 0.10$ & $3.29 \pm 0.23$ & $251.51 \pm 2.59$ & $219.15 \pm 2.91$ & $25.01 \pm 0.86$ & $1.52 \pm 0,04$ \\
\hline $\mathrm{A} 60 / 25$ & $15.50 \pm 0.09$ & $3.27 \pm 0.24$ & $250.91 \pm 2.68$ & $211.53 \pm 1.45$ & $29.73 \pm 1.30$ & $1.92 \pm 0,07$ \\
\hline $\mathrm{A} 60 / 50$ & $17.50 \pm 0.12$ & $3.25 \pm 0.12$ & $250.98 \pm 2.31$ & $216.79 \pm 2.74$ & $25.89 \pm 0.86$ & $1.48 \pm 0,04$ \\
\hline A60/75 & $16.00 \pm 0.08$ & $3.27 \pm 0.14$ & $251.24 \pm 2.57$ & $226.24 \pm 2.66$ & $19.44 \pm 0.83$ & $1.22 \pm 0,05$ \\
\hline A $80 / 00$ & $23,18 \pm 0.11$ & $3.25 \pm 0.13$ & $250.13 \pm 2.22$ & $211.91 \pm 2.26$ & $28.67 \pm 1.04$ & $1.24 \pm 0,04$ \\
\hline A $80 / 25$ & $25.07 \pm 0.13$ & $3.30 \pm 0.25$ & $247.66 \pm 2.59$ & $212.52 \pm 2.63$ & $26.60 \pm 0.68$ & $1.06 \pm 0,02$ \\
\hline $\mathrm{A} 80 / 50$ & $26.02 \pm 0.08$ & $3.27 \pm 0.20$ & $248.87 \pm 2.66$ & $112.93 \pm 8.12$ & $64.96 \pm 2.51$ & $2.50 \pm 0,09$ \\
\hline $\mathrm{A} 80 / 75$ & $27.50 \pm 0.11$ & $3.24 \pm 0.21$ & $253.71 \pm 2.57$ & $212.52 \pm 2.93$ & $31.01 \pm 0.70$ & $1.13 \pm 0,02$ \\
\hline A90/00 & $31.20 \pm 0.08$ & $3.29 \pm 0.18$ & $248.39 \pm 2.44$ & $202.01 \pm 2.75$ & $34.28 \pm 0.72$ & $1.10 \pm 0,02$ \\
\hline A90/25 & $30.47 \pm 0.15$ & $3.29 \pm 0.28$ & $248.03 \pm 2.93$ & $209.70 \pm 2.29$ & $28.92 \pm 0.95$ & $0.95 \pm 0,03$ \\
\hline A90/50 & $30.57 \pm 0.13$ & $3.27 \pm 0.18$ & $251.44 \pm 2.58$ & $216.71 \pm 3.08$ & $26.47 \pm 0.89$ & $0.87 \pm 0,03$ \\
\hline A90/75 & $29.33 \pm 0.09$ & $3.31 \pm 0.24$ & $246.53 \pm 2.06$ & $208.71 \pm 2.74$ & $28.44 \pm 0.83$ & $0.97 \pm 0,03$ \\
\hline
\end{tabular}

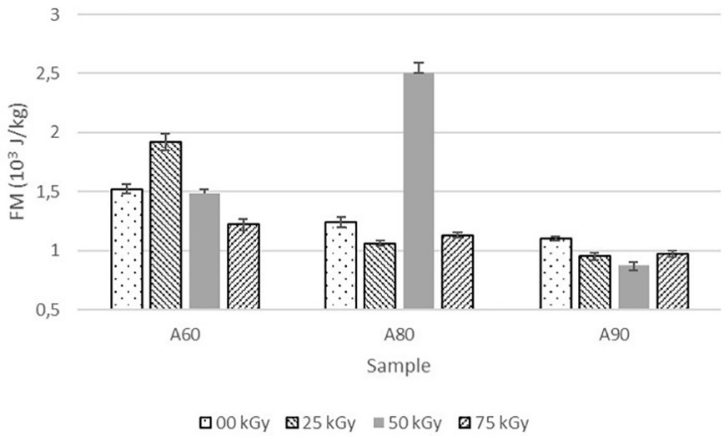

Figure 2. Merit factor of composites with $60 \%, 80 \%$ and $90 \%$ alumina concentration, non-irradiated and irradiated with $25 \mathrm{kGy}$, $50 \mathrm{kGy}$ and $75 \mathrm{kGy}$.

Table 2. Gel content of UHMWPE, non-irradiated and gamma irradiated with doses of $25 \mathrm{kGy}, 50 \mathrm{kGy}$ and $75 \mathrm{kGy}$.

\begin{tabular}{cc}
\hline Sample & Gel content (\%) \\
\hline $\mathrm{A} 00 / 00$ & 91.20 \\
$\mathrm{~A} 00 / 25$ & 97.37 \\
$\mathrm{~A} 00 / 50$ & 100.00 \\
$\mathrm{~A} 00 / 75$ & 99.69 \\
\hline
\end{tabular}

The decrease of gel content for a higher radiation dose is attributed to degradation of UHMWPE, forming free radicals.

\section{$3.3 \mathrm{DSC}$}

The DSC analyses were performed during the first fusion and crystallization. Table 3 shows that the samples irradiated with $50 \mathrm{kGy}$ had the highest values of crystallinity, and among them the largest value was that of the sample 80/50.

\section{$3.4 X$-ray diffraction}

The samples with $80 \%$ alumina were investigated further due to the good ballistic performance displayed by the sample with $80 \%$ alumina irradiated with $50 \mathrm{kGy}$. The purpose was to determine why the ballistic performance increased with radiation dose up to a radiation dose of $50 \mathrm{kGy}$, but decreased when the radiation dose was increased to $75 \mathrm{kGy}$.
Table 3. DSC average results.

\begin{tabular}{cccccc}
\hline Sample & $\begin{array}{c}\boldsymbol{T}_{\text {onset }} \\
\left({ }^{\mathbf{C}} \mathbf{C}\right)\end{array}$ & $\begin{array}{c}\boldsymbol{T}_{\text {maxx }} \\
\left({ }^{\circ} \mathbf{C}\right)\end{array}$ & $\begin{array}{c}\boldsymbol{T}_{\text {end }} \\
\left({ }^{\mathbf{o}} \mathbf{C}\right)\end{array}$ & $\begin{array}{c}\Delta \boldsymbol{H}_{\text {fusion }} \\
(\mathbf{J} / \mathbf{g})\end{array}$ & $\begin{array}{c}\text { Crystallinity } \\
(\mathbf{\%})\end{array}$ \\
\hline $\mathrm{A} 60 / 00$ & 128.8 & 139.4 & 145.7 & 53.02 & 45 \\
$\mathrm{~A} 60 / 25$ & 127.9 & 139.7 & 146.3 & 68.97 & 59 \\
$\mathrm{~A} 60 / 50$ & 128.6 & 142.9 & 152.0 & 103.10 & 88 \\
$\mathrm{~A} 60 / 75$ & 128.7 & 141.4 & 148.7 & 77.91 & 66 \\
$\mathrm{~A} 80 / 00$ & 128.5 & 140.4 & 147.5 & 37.97 & 65 \\
$\mathrm{~A} 80 / 25$ & 130.3 & 141.7 & 148.6 & 44.36 & 76 \\
$\mathrm{~A} 80 / 50$ & 129.2 & 142.1 & 148.1 & 56.21 & 96 \\
$\mathrm{~A} 80 / 75$ & 129.6 & 140.9 & 147.4 & 45.54 & 78 \\
$\mathrm{~A} 90 / 00$ & 126.8 & 136.4 & 143.2 & 15.17 & 52 \\
$\mathrm{~A} 90 / 25$ & 130.0 & 138.5 & 144.5 & 21.30 & 73 \\
$\mathrm{~A} 90 / 50$ & 129.4 & 139.1 & 145.6 & 24.86 & 85 \\
$\mathrm{~A} 90 / 75$ & 130.9 & 140.7 & 147.2 & 23.38 & 80 \\
\hline
\end{tabular}

Figure 3 shows the XRD patterns of samples A80/00, A80/25, A80/50 and A80/75. Except for a broad line at small angles attributed to amorphous UHMWPE, only the diffraction lines of $\alpha$-alumina and UHMWPE are seen, showing that there was no phase transformation due to gamma irradiation.

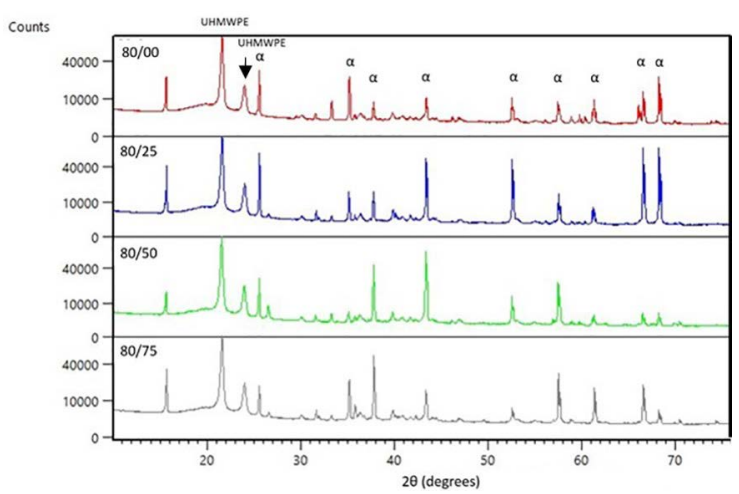

Figure 3. XRD patterns of A80/00, A80/25, A80/50, A80/75 samples. 
In Figure 4, one can see that the amplitude of the broad line goes through a minimum for a radiation dose of $50 \mathrm{kGy}$. This suggests that the crystallinity of UHMWPE increases with increasing radiation dose up to a radiation dose of 50 $\mathrm{kGy}$, but decreases for larger radiation doses.

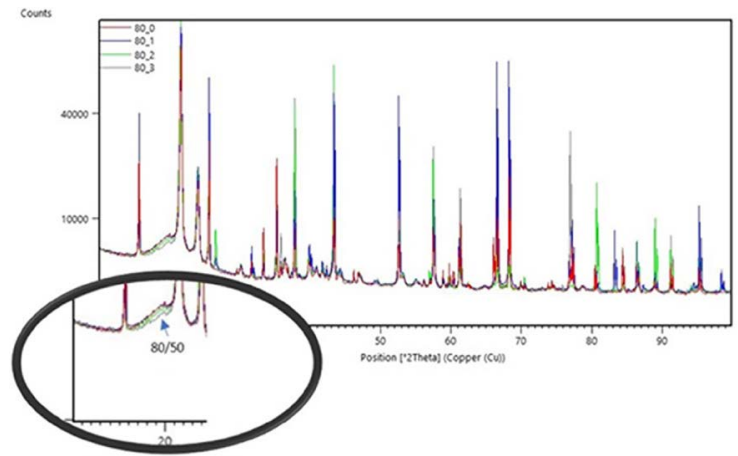

Figure 4. XRD Superimposed XRD patterns of A80/00, A80/25, A80/50, A80/75 samples.

Figure 5 shows amplified views of parts of the diffraction patterns displayed in Figure 4. In the case of the UHMWPE line, there is a significant displacement to the left for the sample submitted to a radiation dose of $50 \mathrm{kGy}$. This is attributed to a relaxation due to increasing crystallinity and is consistent with the decrease in the amplitude of the broad line in Figure 4. In the case of the alumina lines, there is a shift to the right in the samples irradiated with 25 and 75 $\mathrm{kGy}$. In the first case, the compression may be due to loss of water and in the second to radiation-induced microckacks.

\subsection{Images of alumina powder, sample A80/00 and sample $A 80 / 50$}

Figure 6 is an SEM Image of the alumina powder, showing the irregular shape of the grains, which improves the stiffness of the composites.

When impact occurs, compressive shock waves propagate along the thickness of the sample and are responsible for

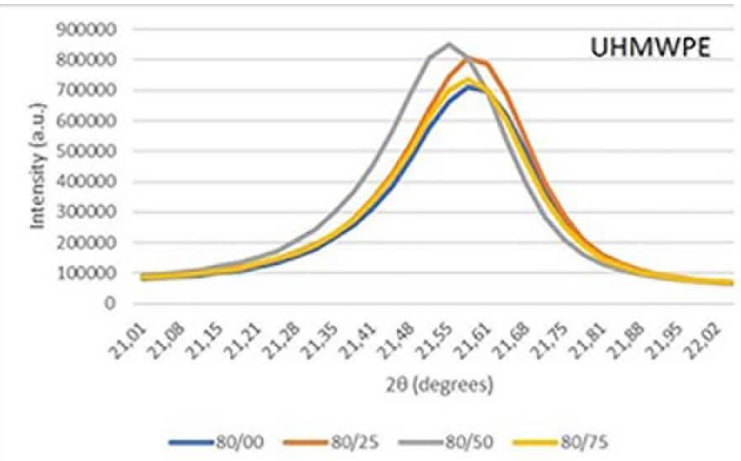

Figure 5. Selected XRD lines of UHMWPE and $\alpha$-alumina. several cracks whose interaction creates subsequently a conical damage zone with ductile and fragile failure, similar to that observed in ceramic tiles ${ }^{19}$. Figure 7 show the conical damage zone in the distal face of an A80/50 sample.

Figure 8 shows microcracking on the distal faces of A 80 and A80/50 samples after the first impact. The main difference between Figures $8 \mathrm{a}$ and $8 \mathrm{~b}$ is that there is evidence for pullout in the irradiated samples as a consequence of increased adhesion between alumina and UHMWPE, as also shown in Figure 9.

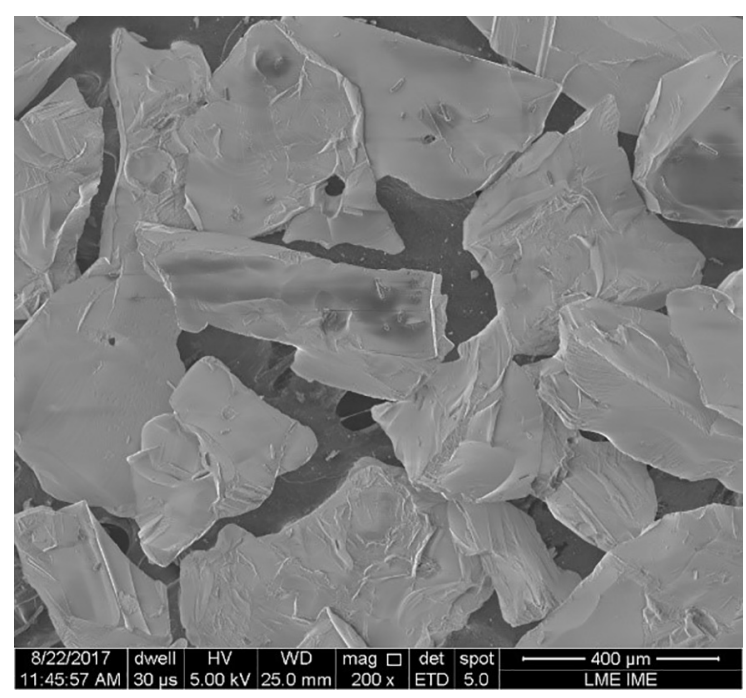

Figure 6. SEM image of the alumina powder.

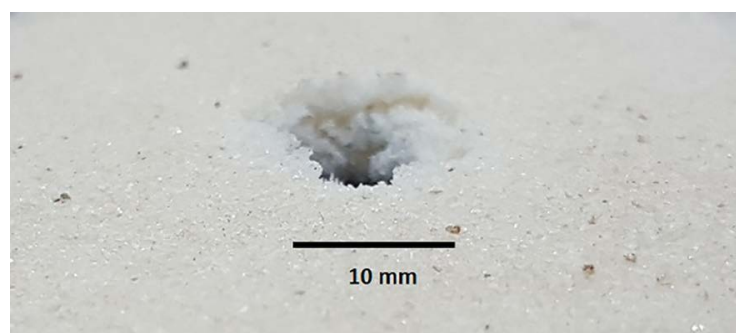

Figure 7. Optical image showing the conical damage zone on the distal face of an A80/50 sample.

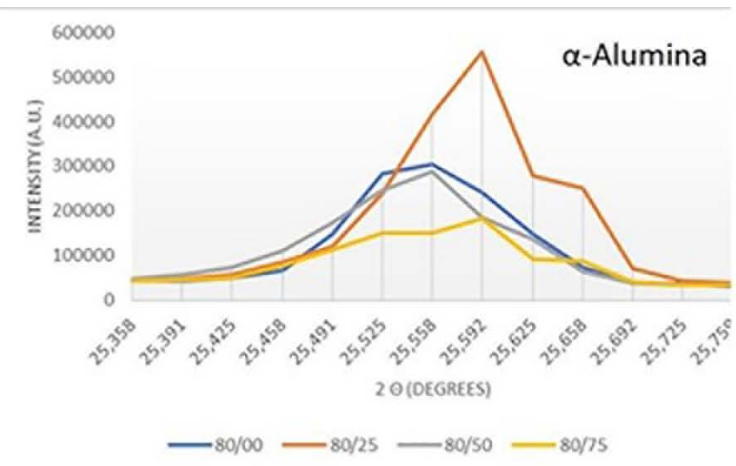



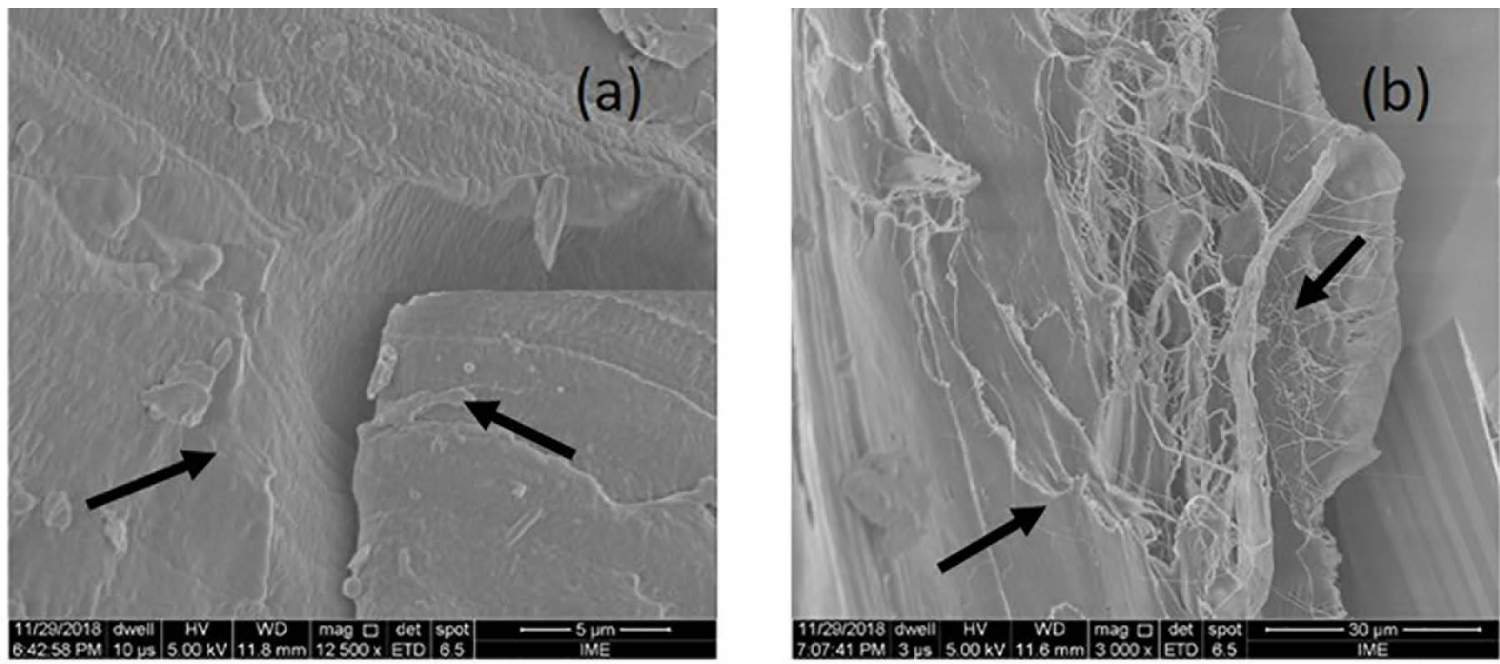

Figure 8. SEM images, after the first impact, of the distal face (a) of an A80/00 sample showing the microcracking without pullout and (b) of an A80/50 sample showing microcracking with pullout.
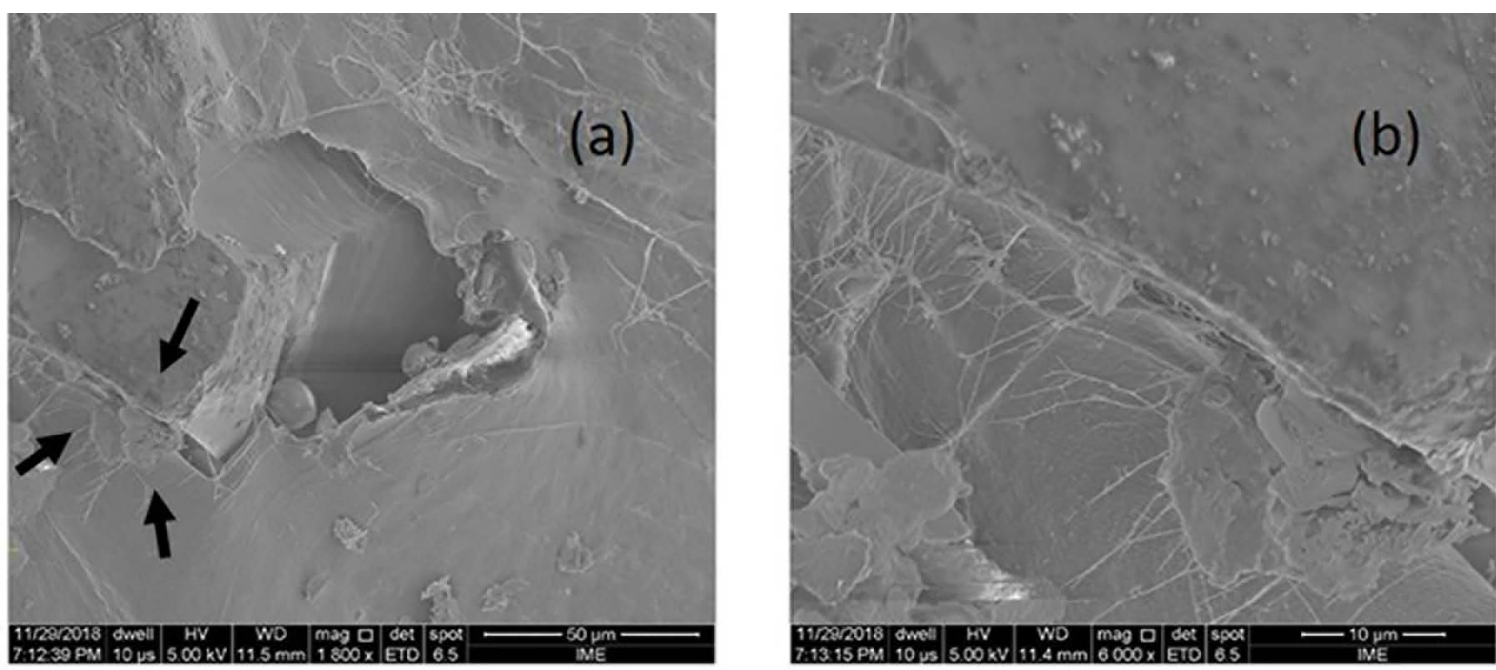

Figure 9. SEM images, after the first impact, (a) of the distal face of an A80/50 sample, showing the region of contact between alumina and UHMWPE, and (b) enlargement of the same region, showing UHMWPE pullout.

\section{Conclusions}

Ballistic tests were performed on gamma-irradiated alumina-UHMWPE composites. The composite with $80 \%$ alumina submitted to a radiation dose of $50 \mathrm{kGy}$ was the one that had the best ballistic properties. Gel content, DSC, $\mathrm{XRD}$ and SEM results suggest that this is due to three effects of gamma radiation: an increased extent of crosslinking, a decrease of the volume fraction of amorphous UHMWPE and an increased adhesion between alumina and UHMWPE. The results also showed that increasing the radiation dose above $50 \mathrm{kGy}$ has adverse effects, probably due to the production of a large number of microcracks that leads to a weakening of the alumina particles and to UHMWPE degradation, generating free radicals.

\section{References}

1. da Luz FS, Lima Junior EP, Louro LHL, Monteiro SN. Ballistic Test of Multilayered Armor with Intermediate Epoxy Composite Reinforced with Jute Fabric. Materials Research. 2015;18(Suppl 2):170-177.

2. Cavallaro PV. NUWC-NPT Technical Report 12,057 - Soft Body Armor: An Overview of Materials, Manufacturing, Testing, and Ballistic Impact Dynamic. Newport: Naval Undersea Warfare Center Division; 2011.

3. Carlucci DE, Jacobson SS. Ballistics: Theory and Design of Guns and Ammunition. Boca Raton: CRC Press; 2008. 496 p.

4. Figueiredo ABS, Lima Júnior EP, Gomes AV, Melo GBM, Monteiro SN, de Biasi RS. Response to Ballistic Impact of Alumina-UHMWPE Composites. Materials Research. 2018;21(5):e20170959. 
5. Madhu V, Ramanjaneyulu K, Bhat TB, Gupta NK. An experimental study of penetration resistance of ceramic armour subjected to projectile impact. International Journal of Impact Engineering. 2005;32(1-4):337-350.

6. Neves JC, Silva GG, Mendes MWD, Bressiani AH, Bressiani JC, Garcia FG. Efeito da irradiação gama nas propriedades mecânicas e térmicas de redes DGEBA/amina cicloalifática com potencial para aplicações médicas. Polímeros. 2013;23(6):814-822.

7. Lima IS, Araújo ES. Efeitos da radiação gama na estrutura e nas propriedades do poliestireno. In: $4^{\text {th }}$ Meeting on Nuclear Appplications; 1997 Aug 18-22; Poços de Caldas, MG, Brazil. Rio de Janeiro: Associação Brasileira de Polímeros (ABPol); 1997. p. 137-139.

8. Shafiq M, Mehmood MS, Yasin T. On the structural and physicochemical properties of gamma irradiated UHMWPE/silane hybrid. Materials Chemistry and Physics. 2013;143(1):425-433.

9. Hobbs LW, Clinard FW Jr., Zinkle SJ, Ewing RC. Radiation effects in ceramics. Journal of Nuclear Materials. 1994;216:291-321.

10. Coutinho FMB, Mello IL, de Santa Maria LC. Polietileno: Principais Tipos, Propriedades e Aplicações. Polímeros. 2003;13(1):1-13.

11. Senatov FS, Gorshenkov MV, Tcherdyntsev VV, Kaloshkin SD, Sudarchikov VA. Fractographic analysis of composites based on ultra high molecular weight polyethylene. Composites Part B: Engineering. 2014;56:869-875.
12. Medvedovski E. Ballistic performance of armor ceramics: Influence of design and structure. Part I. Ceramics International. 2013;36(7):2103-2115.

13. Medvedovski E. Ballistic performance of armor ceramics: Influence of design and structure. Part II. Ceramics International. 2013;36(7):2117-2127.

14. Medvedovski E. Lightweight ceramic composite armor system. Advances in Applied Ceramics. 2006;105(5):241-245.

15. Spiegelberg SH. Characterization of Physical, Chemical, and Mechanical Properties of UHMWPE. In: Kurtz SM, ed. UHMWPE Biomaterials Handbook. $2^{\text {nd }}$ ed. San Diego: Academic Press; 2009. p. 355-368.

16. Azevedo G, Aragão JCT. Apontamentos sobre balística. Rio de Janeiro; 2010.

17. Sherman D. Impact failure mechanisms in alumina tiles on finite thickness support and the effect of confinement. International Journal of Impact Engineering. 2000;24(3):313-328.

18. Bittencourt BA, Ellwanger MV, Nascimento WA, Belchior LF, Araújo EM, Melo TJA. Moldagem por compressão a frio do polietileno de ultra alto peso molecular. Parte 1: Influência do tamanho, distribuição e morfologia da partícula na densidade a verde. Polímeros. 2009;19(3):224-230.

19. Bresciani LM, Manes A, Giglio M. An analytical model for ballistic impacts against ceramic tiles. Ceramics International. 2018;44(17):21249-21261. 